Research Article

\title{
Synthesis, Crystal Structure, Hirshfeld Surface, and Physicochemical Characterization of New Salt Bis(2-ethyl-6-methylanilinium)tetrachloromercurate (II) $\left[\mathrm{C}_{9} \mathrm{H}_{14} \mathrm{~N}\right]_{2} \mathrm{HgCl}_{4}$
}

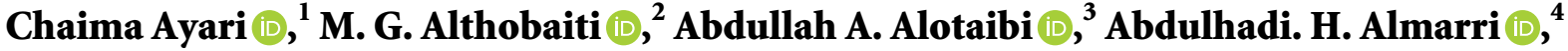 \\ Valeria Ferretti $\mathbb{D}^{5}{ }^{5}$ Cherif Ben Nasr $\mathbb{D}^{1},{ }^{1}$ and Mohamed Habib Mrad $\mathbb{D}^{1,3}$ \\ ${ }^{1}$ Université de Carthage, Laboratoire de Chimie des Matériaux, Faculté des Sciences de Bizerte, Jarzouna 7021, Tunis, Tunisia \\ ${ }^{2}$ Departmentof Physics, College of Science, Taif University, P. O. Box 11099, Taif 21944, Saudi Arabia \\ ${ }^{3}$ Department of Chemistry, College of Sciences and Humanities, Shaqra University, Ad-Dawadmi 11911, Saudi Arabia \\ ${ }^{4}$ Department of Chemistry, College-AllwajhUniverity of Tabuk, Tabuk 71421, Saudi Arabia \\ ${ }^{5}$ Department of Chemical and Pharmaceutical Sciences and Center for StructuralDiffractometry, via Fossato di Mortara 17, \\ Ferrara I-44121, Italy
}

Correspondence should be addressed to Mohamed Habib Mrad; m.mrad@su.edu.sa

Received 11 April 2021; Revised 24 May 2021; Accepted 19 June 2021; Published 2 July 2021

Academic Editor: Marcelino Maneiro

Copyright ( 12021 Chaima Ayari et al. This is an open access article distributed under the Creative Commons Attribution License, which permits unrestricted use, distribution, and reproduction in any medium, provided the original work is properly cited.

In this paper, a new organic salt bis(2-ethyl-6-methylanilinium)tetrachloromercurate (II)) has been synthesized, characterized, and studied theoretically using DFT. The synthesized compound was found to crystallize in the monoclinic system with space group P21/c with the following unit cell parameters $a=23.1696(2), b=25.7951$ (6), $c=7.5980$ (4) $\AA, \beta=96.5790(11)^{\circ}$, and $Z=8$. Its atomic arrangement can be described asmutually alternating organic and inorganic entities in the (ab) plane. The cohesion is achieved through $\mathrm{N}-\mathrm{H}$. . .Cl hydrogen bonds and $\pi \ldots \pi$ stacking interacting neighboring aromatic cations. The PXRD was carried out. The intermolecular interactions in the crystal packing were investigated using Hirshfeld surface analysis. Its associated 2D fingerprint plots revealed their contribution quantitatively. High-resolution images of the surface were obtained by the SEM technique, and the EDX spectrum assured the existence of all nonhydrogen atoms. The infrared spectrum was used to gain more information about vibrational modes. Analysis of thermal differential and gravimetric (TGA/DTA) shows two-phase transitions observed at 362 and $394 \mathrm{~K}$. AC conductivity measurements were performed to confirm these two-phase transitions.

\section{Introduction}

The concept of organic salts materials appeared very recently and has attracted attention in scientific research due to their different applications in chemistry. The synergy between the electrical, thermal, and optical properties of inorganic entities and the physicochemical properties of organic materials opens up a vast field of their applications. These materials, made by combining different components, aim to produce desirable properties and functionalities and at the same time reduce or eliminate undesirable effects [1-8].
Mercury has very endearing properties [9-12]. Concerning coordination chemistry, $\mathrm{Hg}$ (II) does not have a specific coordination number because it can adopt several coordination geometry numbers alternating from two to six due to the $\mathrm{d}^{10}$ configuration and the lack of stabilization of the field effects of the ligand $[13,14]$. Thus, some compounds indicate that the $\mathrm{Hg}^{2+}$ ion has unusual coordination geometries, such as the geometry of the pseudocoordinate structure [15] and the heptacoordinate structure [16]. Therefore, Hg-based coordination compounds can result in a wide range of supramolecular structures ranging from 
discrete coordination complexes to coordination polymers [17-20]. Nevertheless, the most frequent formula of this group is $\mathrm{R}_{2}\left[\mathrm{MX}_{4}\right]$, where $M$ represents the divalent metal, $X$ can be a halogen atom (chlorine, bromine or an iodine atom), and $R$ represents an organic group. When the $R$ group is a protonated amine (cyclic or acyclic), a wide variety of those complexes are known [21,22]. As for the organic group, we oriented our study towards aniline because of its technological uses in various industrial processes such as dyes and pigments. Several compounds of this family are also used as intermediates in the manufacture of herbicides, insecticides, pharmaceuticals for the design of bactericidal agents, agricultural chemicals, and several industrial and commercial purposes. It has also been used for the synthesis of molecules with significant potential nonlinear optical effects [23-27].

Considering the fascinating properties of halogenomercurate (II) and its emerging possibilities widens the development of such organic salts. So, this work reports the synthesis of a new compound bis(2-ethyl-6-methylanilinium) tetrachloromercurate (II) $\left[\mathrm{C}_{9} \mathrm{H}_{14} \mathrm{~N}\right]_{2} \mathrm{HgCl}_{4}$. Its $\mathrm{X}$-ray crystal structure, PXRD, spectroscopic features (FTIR, SEM, EDX), and AC conductivity have been exploited. TG/DTA coupling has also been executed and commented on. The characteristics mentioned above helped understand and delineate the intermolecular interactions of crystal structure and HS along with its fingerprint plots.

\section{Experimental Procedures}

2.1. Assembling $\left[\mathrm{C}_{9} \mathrm{H}_{14} \mathrm{~N}_{2} \mathrm{HgCl}_{4}\right.$. The title compound bis(2ethyl-6-methylanilinium)tetrachloromercurate (II) was synthesized by acid-base reaction between the amine 2ethyl-6-methylaniline (C9H13N) and mercury (II) chloride.

$0.28 \mathrm{~mL}$ of $\mathrm{C}_{9} \mathrm{H}_{13} \mathrm{~N}(2 \mathrm{mmol})$ was dissolved in ethanol, drooped to a mixture of $0.275 \mathrm{~g}$ of mercury chloride $(1 \mathrm{mmol})$, dissolved in a small amount of water and $10 \mathrm{~mL}$ of concentrated $\mathrm{HCl}$, maintained under stirring for 30 minutes, and then left to evaporate slowly at ambient temperature. The chemical reaction equation is as follows:

$$
\mathrm{HgCl}_{2}+2 \mathrm{C}_{9} \mathrm{H}_{13} \mathrm{~N}+2 \mathrm{HCl} \longrightarrow\left[\mathrm{C}_{9} \mathrm{H}_{14} \mathrm{~N}_{2} \mathrm{HgCl}_{4}+\frac{1}{2} \mathrm{H}_{2}\right. \text {, }
$$

After three weeks, pale brown plate crystals were obtained with good quality for single X-ray diffraction analysis. The elemental analysis of the prepared compound yielded that it comprises N: 4.35\%/4.55\%; C: $34.94 \% / 35.14$; and H: $4.23 \% / 4.55 \%$ (exp./theor.).

\subsection{Characterizations}

2.2.1. Powdered X-ray Diffraction Studies (PXRD). D8 Advance Bruker powder diffractometer has been employed using $\mathrm{Cu}-\mathrm{K} \alpha$ radiation with a $2 \theta$ in the range between 3.5 and $50^{\circ}$. Recording the PXRD patterns has been accomplished using mercury program and the single crystal data [28]. PXRD data were captured using a Nonius Kappa CCD diffractometer, and the absorptions were corrected employing the DENZO-SMN package [29]. The direct method was used to solve the structure [30], which is then refined by exploding the SHELXL2014/7 program on $\mathrm{F}^{2}$ utilizing the full-matrix least-squares method [31]. All other calculations were executed with WINGX [32]. The C9 and C18 methyl-terminal groups were found to be disordered over two equivalent positions (occupancy factor 0.5). Experimental details are given in Table 1.

JEOL-6610LV electron microscope operating at $30 \mathrm{kV}$ coupled with an Oxford X-Max microanalysis system has been used to get the compound SEM/EDX patterns.

The projections of the organic salt structure and the ORTEP view were drawn using the DIAMOND 2.0 program [33]. The Crystal Explorer 3.1 software was used for evaluating the intermolecular interactions and exploring the Hirshfeld surface [34].

2.2.2. FT-IR Spectra. The FT-IR spectrum was recorded at ambient conditions using a Nicolet 5700 spectrophotometer from potassium bromide ( $\mathrm{KBr}$ ) with a scan range from 4000 to $400 \mathrm{~cm}^{-1}$.

2.2.3. Thermal Analysis. PYRIS 1 TGA instrument was employed in recording TGA/DTA spectra by varying the temperature from 300 to $700 \mathrm{~K}$ with a heating rate of $10 \mathrm{~K}$ $\min ^{-1}$ under inert nitrogen atmosphere.

2.2.4. Conductivity Measurements. In order to measure the DC resistivity of the samples, the contacts were deposited using silver paste on the opposite faces of the samples, which is pressed into circular pellets of $6 \mathrm{~mm} \times 2 \mathrm{~mm}$ dimension. DC resistivity measurement was performed using a two-probe resistivity set up at room temperature by applying a voltage up to $5 \mathrm{~V}$ using DC resistivity setup of marine India. The setup is interfaced with a computer through the RS232 cable and supported by automated software. DC resistivity measurement was performed and calculated according to the formula:

$$
R=\frac{\rho l}{A},
$$

where $\rho$ is resistivity and $A$ is the area of the sheet.

\section{Results and Discussion}

3.1. X-Ray Powder Diffraction Analysis. The experimental and simulated PXRD patterns are shown in Figure 1. It can be seen that the simulated X-ray powder diffraction pattern closely resembles the experimental pattern where most of the positions of the peaks coincide with each other. We conclude that the synthesized bulk and the crystal data used for diffraction are homogenous.

3.2. X-Ray Microanalyses and Micrographs. The surface morphology of the grown crystal $\left(\mathrm{C}_{9} \mathrm{H}_{14} \mathrm{~N}\right)_{2} \mathrm{HgCl}_{4}$, obtained using the scanning electron microscope, is given in Figures 2(a)-2(c). The surface morphology appears as an 
TABLe 1: Summary of experimental details.

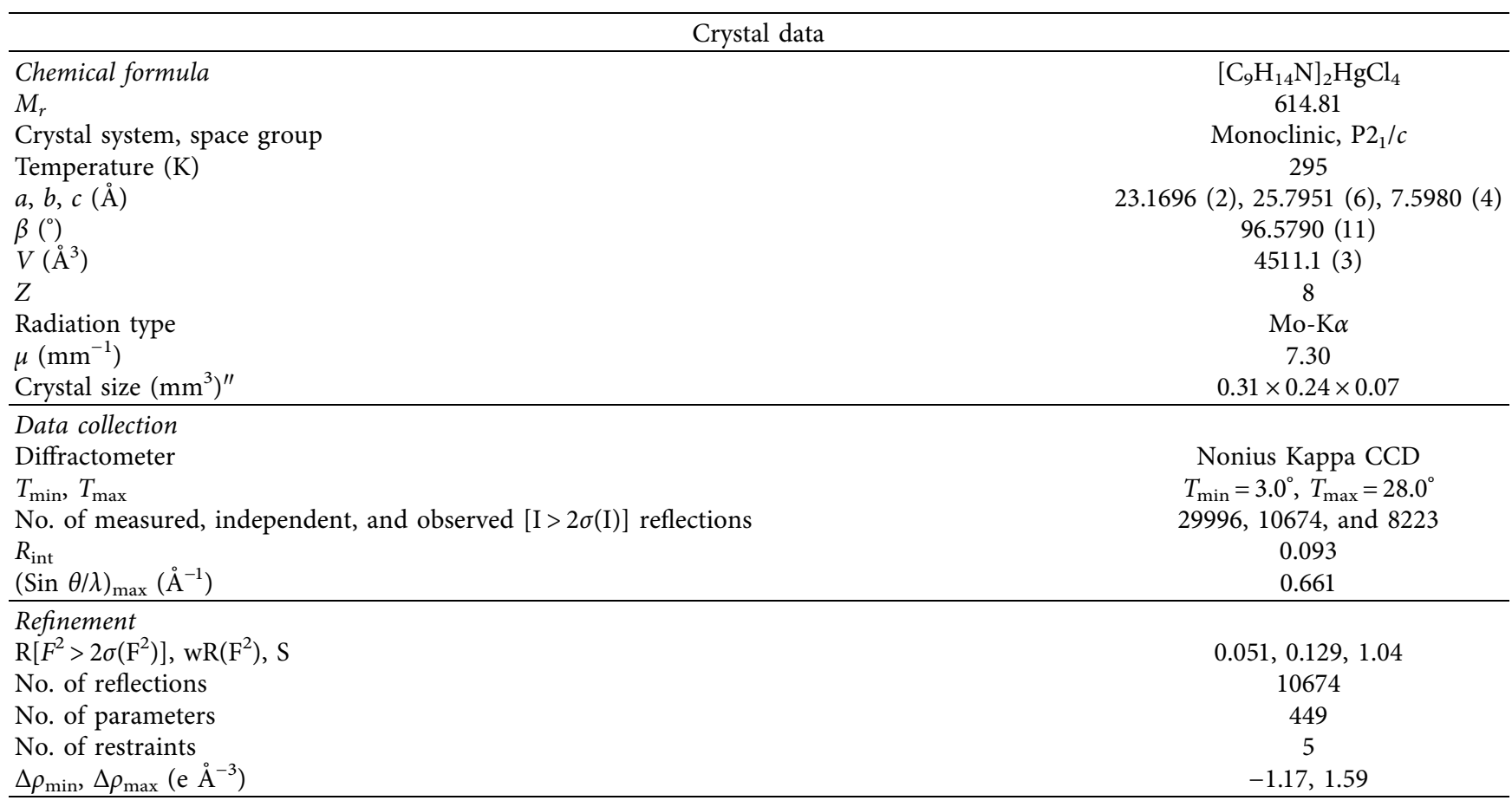

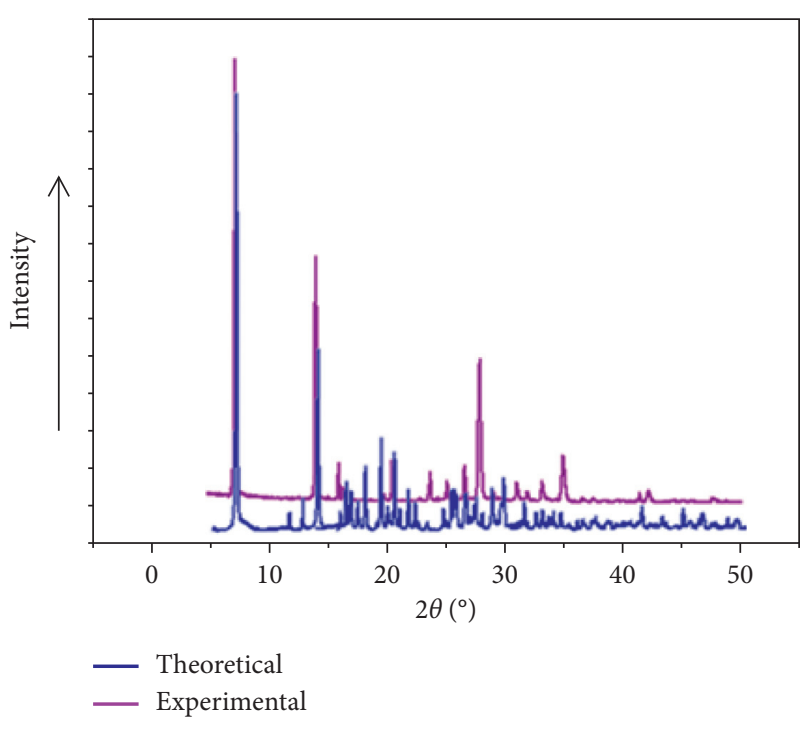

FIGURE 1: Patterns of the simulated and experimental powder XRD for $\left(\mathrm{C}_{9} \mathrm{H}_{14} \mathrm{~N}\right)_{2} \mathrm{HgCl}_{4}$.

assembly of fragments with a flat surface and uniformly distributed, indicating good quality. Moreover, EDX, a valuable tool to identify the elements of higher atomic numbers in crystals, demonstrated the presence of the majority of the atoms (carbon, mercury, chloride, and nitrogen) (Figure 2(d)).

3.3. Description of the Structure. Figure 3 shows the ORTEP of $\left(\mathrm{C}_{9} \mathrm{H}_{14} \mathrm{~N}\right)_{2} \mathrm{HgCl}_{4}$. The asymmetric unit of the prepared salt is formed by two tetrachloromercurate $\left[\mathrm{HgCl}_{4}\right]^{2-}$ anions and four crystallographic independent 2-ethyl-6- methylanilinium $\left(\mathrm{C}_{9} \mathrm{H}_{14} \mathrm{~N}\right)^{+}$organic cations. It is worth noting that the methyl-terminal groups $\mathrm{C} 9$ and $\mathrm{C} 18$ are disordered over two equivalent positions (occupancy factor: $0.5: 0.5)$. In this compound, the cations are located among the inorganic anions, and the N-H. . Cl hydrogen bonds provide the linkage between the cationic and anionic entities (Figure 4). The N. .Cl distances vary from 3.060 (6) to 3.509 (6) $\AA$ (Table 2) so that hydrogen bonds can be classified into two halves, one of them as weak and the other as strong intermolecular contacts [34] (Figure 5). In addition, as the second type of interactions in the crystal packing, the $\pi-\pi$ stacking interaction between aromatic rings adds more stability to the three-dimensional framework with the distance between benzene rings extending from 3.733 to $3.833 \AA$ (Figure 6).

Dimers formed by $\left[\mathrm{HgCl}_{4}\right]^{2-}$ anions were identified by projection of the atomic arrangements in the $(\mathrm{ab})$ plane such that each mercury atom is coordinated by four chlorine atoms located at $(0,0,0) ;((1 / 2), 0,0) ;(0,(1 / 2), 0)$; and $((1 / 2),(1 / 2), 0)$. The Cl-Hg-Cl bond angles vary from 94.50 $(5)^{\circ}$ to $151.12(7)^{\circ}$, and the $\mathrm{Cl}-\mathrm{Hg}$ bond lengths are in the range of $2.389(2)-2.681$ (2) $\AA$. Those characteristics concerning bond lengths and angles listed in Table s1 agree well with those reported for similar compounds $[35,36]$. In the structure of the protonated amine 2-ethyl-6-methylanilinium $\left(\mathrm{C}_{9} \mathrm{H}_{14} \mathrm{~N}\right)^{+}$, the two groups $-\mathrm{CH}_{3}$ and $-\mathrm{CH}_{2}-\mathrm{CH}_{3}$ are arranged on the same plane as their carrier phenyl ring (in the ortho position) since the angles of torsion involving these substituents have the values of $0^{\circ}$.The bond lengths and angles are grouped in Table 3 and emphasized that the carbons of the phenyl rings are regular, agreeing well with those reported for other compounds with anilinium groups [37-39]. 


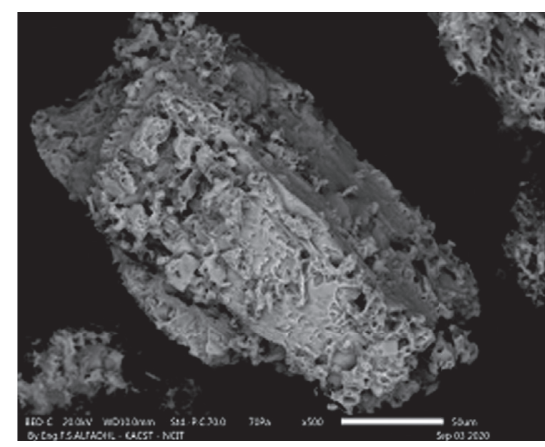

(a)

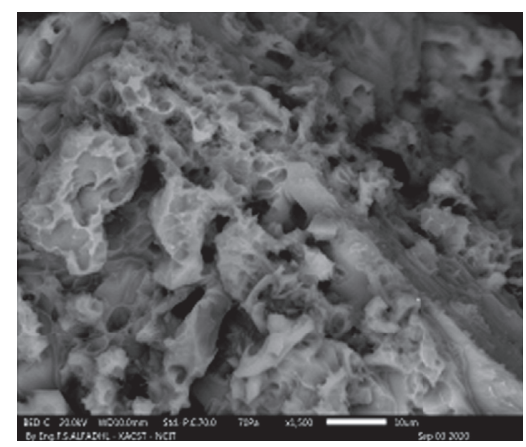

(b)

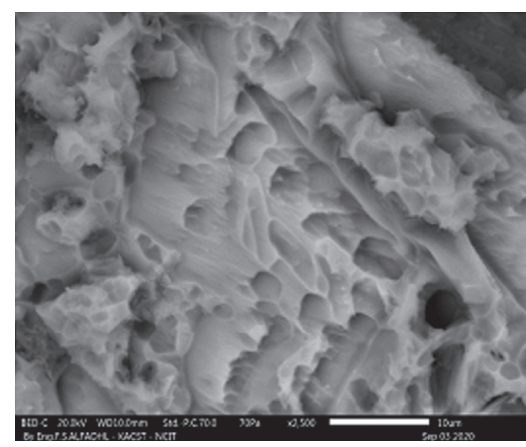

(c)

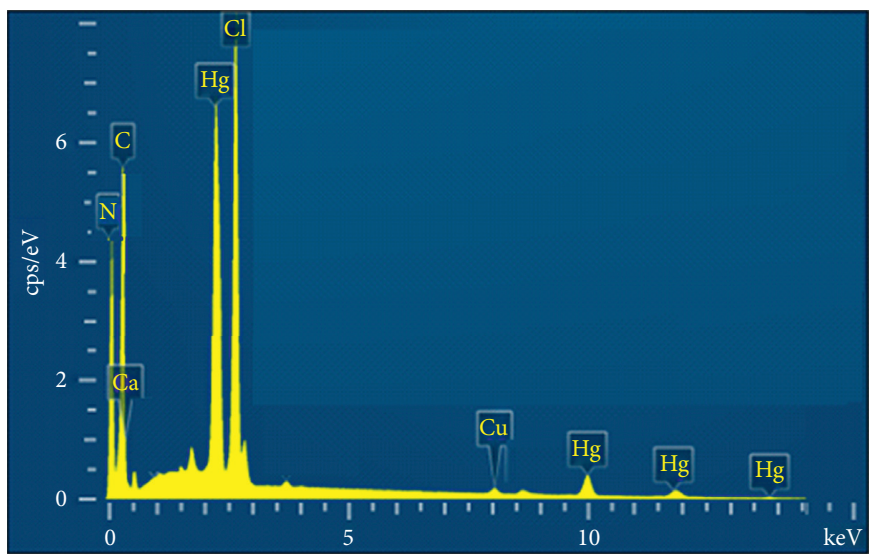

(d)

Figure 2: (a-c) SEM images; (d) typical spectrum of $\left(\mathrm{C}_{9} \mathrm{H}_{14} \mathrm{~N}\right)_{2} \mathrm{HgCl}_{4}$.

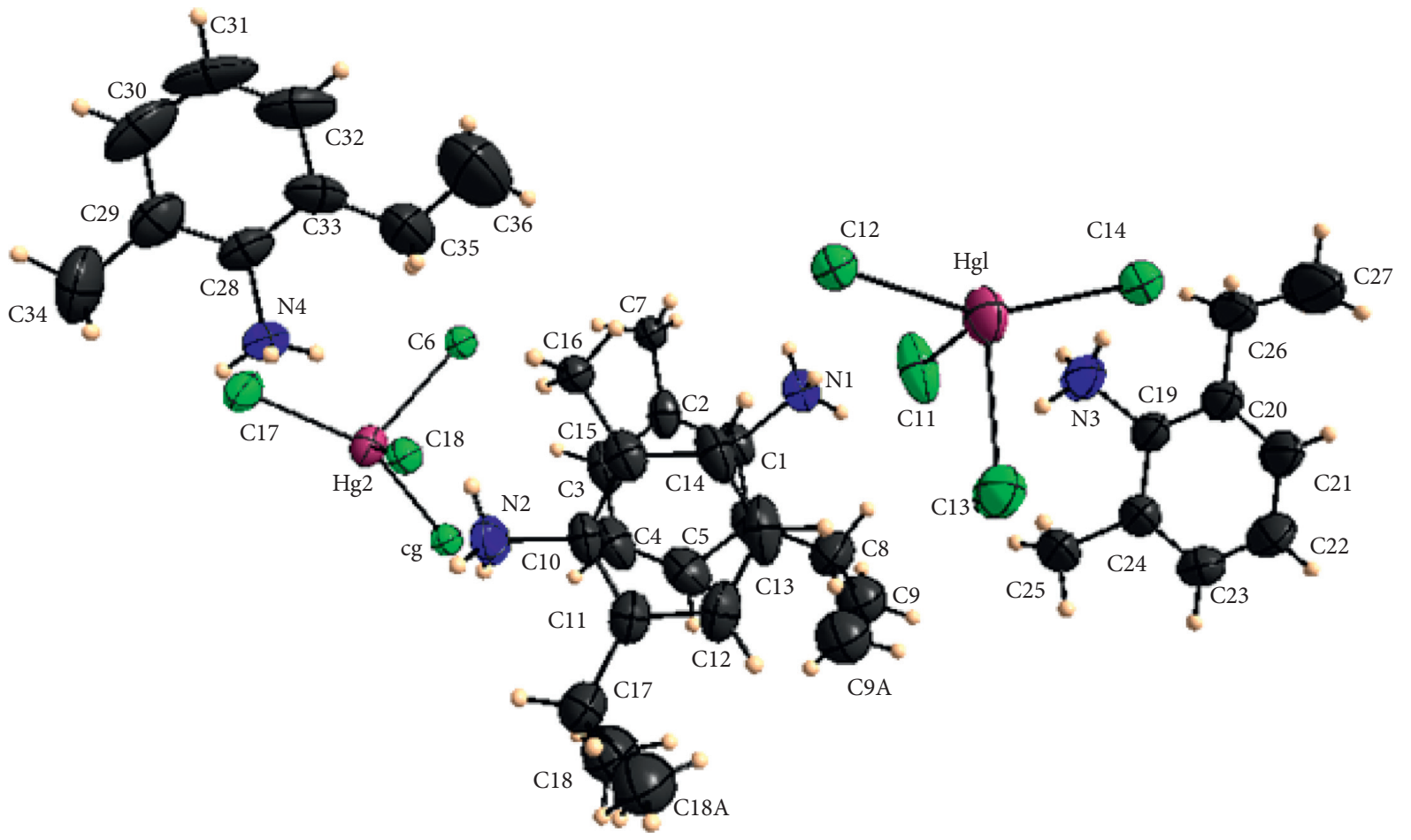

Figure 3: ORTEP of the $\left(\mathrm{C}_{9} \mathrm{H}_{14} \mathrm{~N}\right)_{2} \mathrm{HgCl}_{4}$ compound showing both atom label and thermal ellipsoid, plotted at $50 \%$ probability level. 


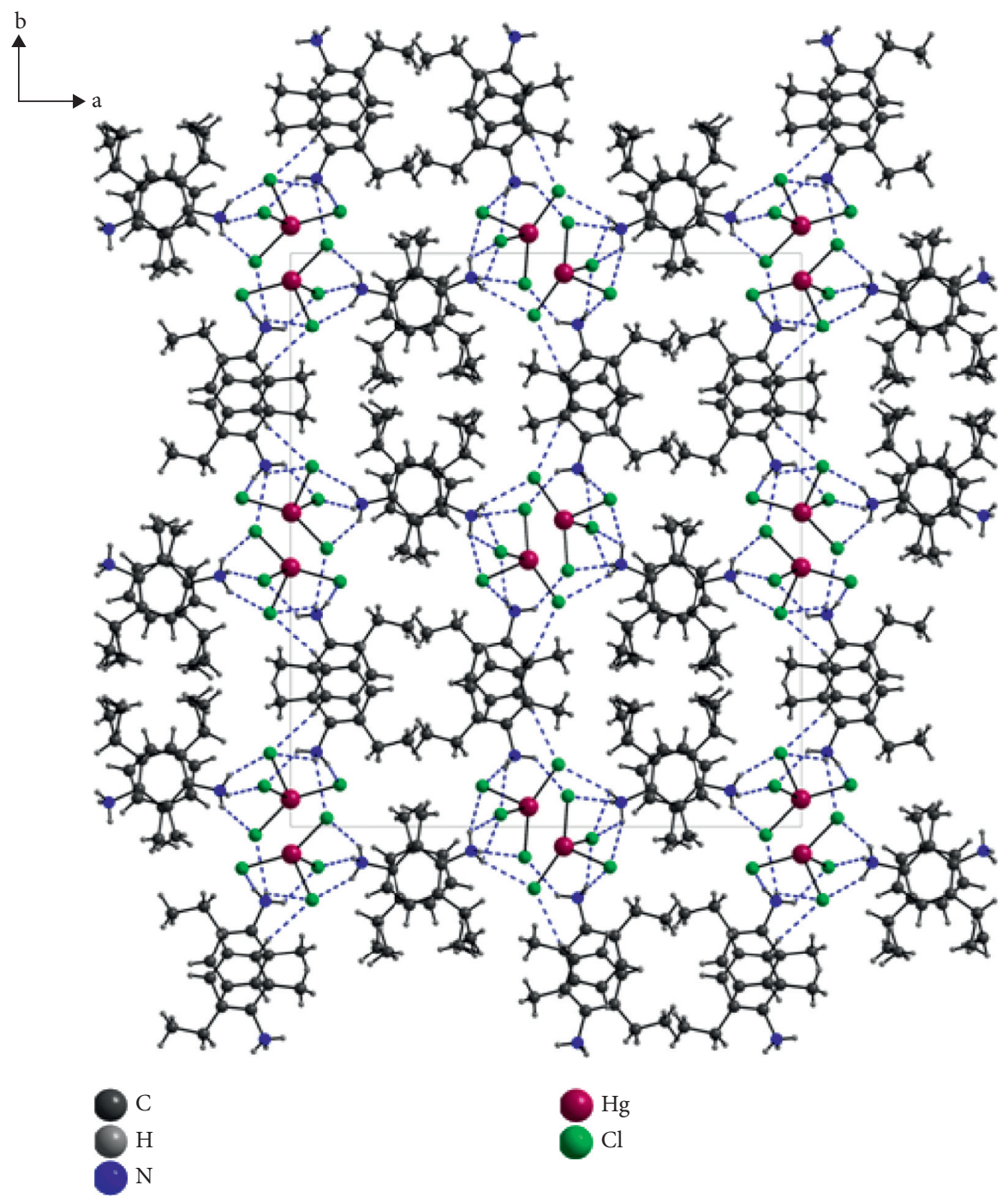

Figure 4: Projection along the $c$-axis arrangement of $\left(\mathrm{C}_{9} \mathrm{H}_{14} \mathrm{~N}\right)_{2} \mathrm{HgCl}_{4}$.

3.4. Hirshfeld Surface Analysis. The Hirshfeld surfaces of the synthesized compound were plotted over a $d_{\text {norm }}$. The shape index and curvedness are shown in Figure 7. The intensive hot red spots on the $d_{\text {norm }}$ surface are attributed to the $\mathrm{Cl}$ and $\mathrm{H}$ atoms interactions (Figure 8 ). Both blue and red triangles appear on the shape index's cartography, and the large flat green areas delimited by the blue outline in the cartography of curvedness indicate the existence of the $\pi$ - $\pi$ stacking interactions between the aromatics cycles of the organic cations. The enrichment ratio $E_{\mathrm{XY}}$ for a pair of elements $(X$, $Y$ ) is calculated and reported in Table s2. Moreover, the full fingerprint plots of the main contacts involved in the title compound are illustrated in Figure 9(a). Globally, H...H contacts are the most plenty interactions with a contribution percentage reaching 49\% (Figure 9(b)) and appear as a large region plot with a high concentration in the middle due to the abundance of the $\mathrm{H}$ atoms on the surface, and they are moderately enriched $\left(E_{\mathrm{HH}}=1.02\right)$. The $\mathrm{H} . . \mathrm{Cl} / \mathrm{Cl} \ldots \mathrm{H}$ contacts ranked as the second most abundant interactions (34\%) due to the plenty of hydrogen and chloride atoms on the molecular surface $\left(S_{\mathrm{H}}=69.3 \%\right.$ and $\left.S_{\mathrm{Cl}}=20.85 \%\right)$ with an enrichment ratio $E_{\mathrm{HCl}}=1.17$ which manifested as two sharp spikes in the 2D fingerprint plot (Figure 9(c)). Indeed, there are fourteen hydrogen bonds of type N-H...Cl (Table 3). $5.9 \%$ of the Hirshfeld surface resulting from C. ..H/H. ..C contact appears in Figure $9(\mathrm{~d})$ as a symmetric pair of wings with an enrichment ratio $E_{\mathrm{CH}}=0.19$. This low value revealed that these pairs tend to repel contact with each other. The C. . C contacts, which refer to the $\pi-\pi$ stacking interaction SC $=21.7 \%$, contribute with $4.7 \%$ of the Hirshfeld surface (Figure 9(e)). The other intermolecular contacts are $\mathrm{Hg} . . \mathrm{Cl}$ : 3.5\% (Figure 9(f)), Cl. . Cl; 2.1\% (Figure 9(g)), and Hg. . H; $0.7 \%$ (Figure $9(\mathrm{~h})$ ) contributing lower to the surface.

These contact contributions are in agreement with those of $\left[\mathrm{CuCl}_{2}\left(\mathrm{C}_{14} \mathrm{H}_{10} \mathrm{~N}_{2}\right)\left(\mathrm{H}_{2} \mathrm{O}\right)\right] \mathrm{H}_{2} \mathrm{O}$ for which the $\mathrm{H}$...H contacts are the most abundant $44.0 \%$ followed by $\mathrm{H}$. . Cl contact $23.1 \%$ and then the C...H contact $13.2 \%$ [40].

3.5. Vibrational Study. The FT-IR measurements were used to recognize the $\left(\mathrm{C}_{9} \mathrm{H}_{14} \mathrm{~N}\right)_{2} \mathrm{HgCl}_{4}$ functional groups. Figure 10 displays the infrared spectrum governed by the 


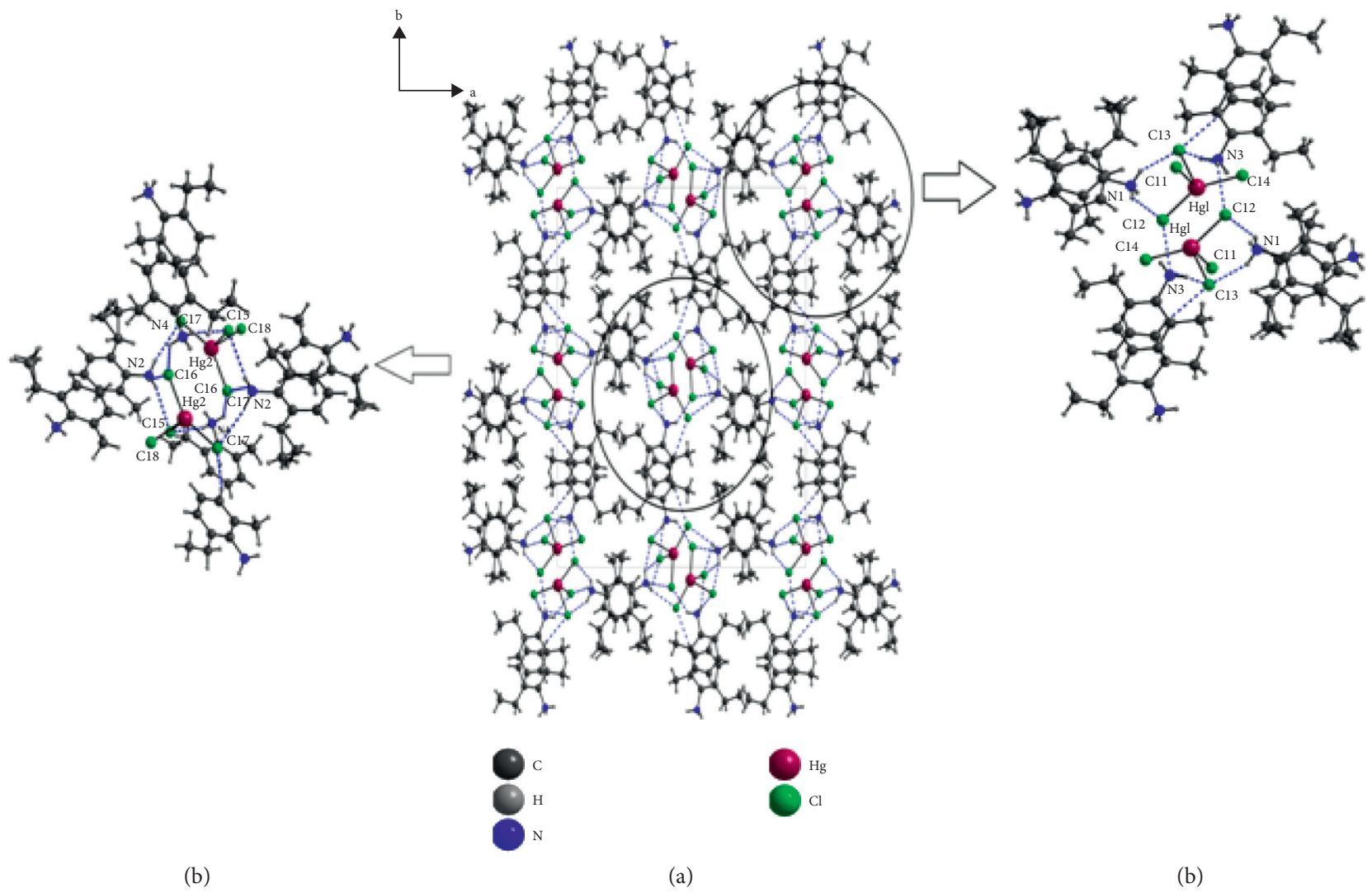

Figure 5: (a) The $c$-axis atomic arrangement projection of $\left(\mathrm{C}_{9} \mathrm{H}_{14} \mathrm{~N}\right)_{2} \mathrm{HgCl}_{4}$. (b) Different hydrogen bonds with dotted lines observed in title salt.

TABle 2: H-bonds geometry ( $\left.\AA^{\circ}{ }^{\circ}\right)$.

\begin{tabular}{lcccc}
\hline $\mathrm{D}-\mathrm{H} \cdots \mathrm{A}$ & $\mathrm{D}-\mathrm{H}(\AA)$ & $\begin{array}{c}\mathrm{H} \cdots \mathrm{A} \\
(\AA)\end{array}$ & $\begin{array}{c}\mathrm{D} \cdots \mathrm{A} \\
(\AA)\end{array}$ & $\mathrm{D}-\mathrm{H} \cdots \mathrm{A}\left(^{\circ}\right)$ \\
\hline $\mathrm{N} 1-\mathrm{H} 1 \mathrm{~A} \cdots \mathrm{Cl} 2^{\mathrm{I}}$ & 0.89 & 2.48 & $3.267(6)$ & 147 \\
$\mathrm{~N} 1-\mathrm{H} 1 \mathrm{~B} \cdots \mathrm{Cl} 3^{\mathrm{i}}$ & 0.89 & 2.35 & $3.161(6)$ & 152 \\
$\mathrm{~N} 1-\mathrm{H} 1 \mathrm{~B} \cdots \mathrm{Cl} 1$ & 0.89 & 2.30 & $3.094(6)$ & 149 \\
$\mathrm{~N} 2-\mathrm{H} 2 \mathrm{~A} \cdots \mathrm{Cl} 5$ & 0.89 & 2.85 & $3.360(6)$ & 118 \\
$\mathrm{~N} 2-\mathrm{H} 2 \mathrm{~A} \cdots \mathrm{Cl} 8^{\mathrm{i}}$ & 0.89 & 2.56 & $3.096(6)$ & 119 \\
$\mathrm{~N} 2-\mathrm{H} 2 \mathrm{~B} \cdots \mathrm{Cl} 7^{\mathrm{ii}}$ & 0.89 & 2.70 & $3.509(6)$ & 151 \\
$\mathrm{~N} 2-\mathrm{H} 2 \mathrm{C} \cdots \mathrm{Cl} 6$ & 0.89 & 2.45 & $3.248(8)$ & 149 \\
$\mathrm{~N} 3-\mathrm{H} 3 \mathrm{~A} \cdots \mathrm{Cl} 4$ & 0.89 & 2.70 & $3.488(8)$ & 148 \\
$\mathrm{~N} 3-\mathrm{H} 3 \mathrm{~B} \cdots \mathrm{Cl} 1$ & 0.89 & 2.41 & $3.093(6)$ & 134 \\
$\mathrm{~N} 3-\mathrm{H} 3 \mathrm{C} \cdots \mathrm{Cl} 2^{\mathrm{iii}}$ & 0.89 & 2.69 & $3.215(6)$ & 119 \\
$\mathrm{~N} 3-\mathrm{H} 3 \mathrm{C} \cdots \mathrm{Cl} 3^{\mathrm{i}}$ & 0.89 & 2.68 & $3.289(8)$ & 127 \\
$\mathrm{~N} 4-\mathrm{H} 4 \mathrm{C} \cdots \mathrm{Cl} 5^{\mathrm{iv}}$ & 0.89 & 2.33 & $3.187(6)$ & 161 \\
$\mathrm{~N} 4-\mathrm{H} 4 \mathrm{~B} \cdots \mathrm{Cl} 8$ & 0.89 & 2.30 & $3.060(6)$ & 14 \\
$\mathrm{~N} 4-\mathrm{H} 4 \mathrm{C} \cdots \mathrm{Cl} 6^{\mathrm{v}}$ & 0.89 & 2.56 & $3.187(6)$ & 128 \\
\hline
\end{tabular}

Symmetry Codes. i: $x, y, z+1$; ii: $-x+1,-y,-z+2$; iii: $-x+2,-y,-z+1$; iv: $x, y$, $z-1 ; \mathrm{v}:-x+1,-y,-z+1$.

cation's vibration bands since the $\mathrm{Hg}-\mathrm{Cl}$ internal vibrational bands manifest below $400 \mathrm{~cm}^{-1}$ [4-44].

The two large bands in the high-frequency region, at 2973 and $2564 \mathrm{~cm}^{-} 1$, may be imputed to $v_{\mathrm{s} \text {, as }}(\mathrm{N}-\mathrm{H})_{\mathrm{Ar}}$ and $v_{\mathrm{s} \text {,as }}(\mathrm{C}-\mathrm{H})_{\mathrm{Ar}}$. The hydrogen bonds of type $\mathrm{N}-\mathrm{H}$. . Cl affect the region's absorption position, and the bands recorded at 1590 , and $1559 \mathrm{~cm}^{-1}$ correspond to $\delta_{(\mathrm{NH})}$ of the $\mathrm{NH}_{3}$ groups. However, the two intense peaks detected at 1618 and
$1500 \mathrm{~cm}^{-1}$ are assigned to the valence vibration $v(\mathrm{C}=\mathrm{C})$ of the aromatic rings. Besides, the vibration bands observed in the range $1450-1150 \mathrm{~cm}^{-1}$ are characteristic of $\delta_{\mathrm{s} \text {, as }}\left(\mathrm{CH}_{3}\right)$, $\delta_{\mathrm{s} \text {,as }}\left(\mathrm{NH}_{3}\right)$, and $\delta_{\mathrm{s} \text {,as }}(\mathrm{C}-\mathrm{N})$. While the low-intensity bands appearing between 1000 and $500 \mathrm{~cm}^{-1}$ correspond to the deformations $\delta\left(\mathrm{C}_{\text {aryl }}-\mathrm{H}\right), \delta\left(\mathrm{C}_{\text {aryl }}-\mathrm{C}_{\text {aryl }}\right), \delta\left(\mathrm{C}_{\text {aryl }}-\mathrm{N}\right)$, and $\gamma(\mathrm{N}-$ $\mathrm{H})$ of the phenyl ring.

3.6. Thermal Analysis. Simultaneous TGA-DTA analyses were carried out to study the thermal stability and the changes of the newly synthesized compound $\left(\mathrm{C}_{9} \mathrm{H}_{14} \mathrm{~N}\right)_{2} \mathrm{HgCl}_{4}$. The results are shown in Figure 11. A series of endothermic and exothermic peaks are observed on the DTA curve, accompanied by a weight loss on the TGA curve. The two endothermic peaks detected on the DTA curve observed at $362 \mathrm{~K}$ and $391 \mathrm{~K}$ without mass loss correspond to two-phase transitions phenomena. The three exothermic peaks observed a 441,474, and $530 \mathrm{~K}$ with $\Delta \mathrm{H}=-1279.880 \mathrm{~J} / \mathrm{g}, \quad \Delta \mathrm{H}=-903.219 \mathrm{~J} / \mathrm{g}, \quad$ and $\Delta \mathrm{H}=-128.806 \mathrm{~J} / \mathrm{g}$, respectively, correspond to the loss of the two organic cations with a total experimental mass of $45 \%$ compared to the calculated weight loss of $46 \%$. The two exothermic peaks in the DTA curve observed at 561 and $600 \mathrm{~K}$, with $\Delta \mathrm{H}=-22.134 \mathrm{~J} / \mathrm{g}$ and $\Delta \mathrm{H}=-1212.156 \mathrm{~J} / \mathrm{g}$, respectively, are assigned to the elimination of four chlorine atoms (exp/calc: $21.5 \% / 22 \%$ ). The compound completely melts since there is no endothermic peak after $600 \mathrm{~K}$. 

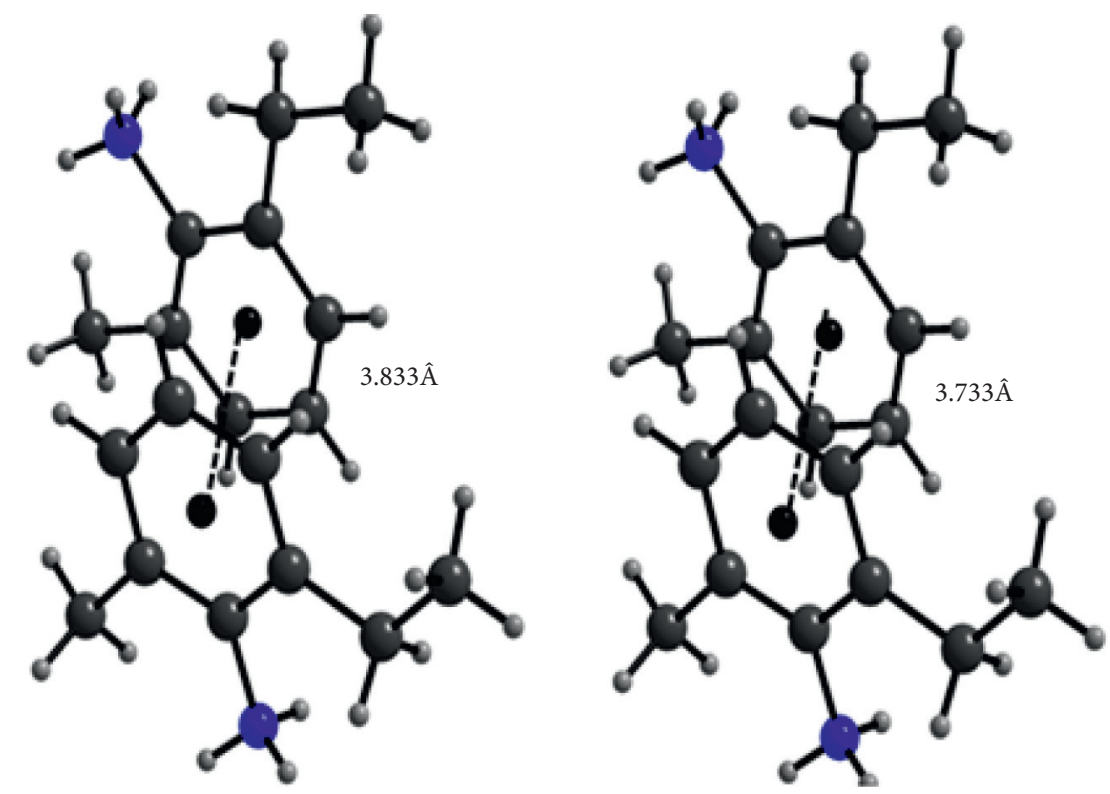

Figure 6: The different $\pi$ - $\pi$ stacking interactions between the neighboring aromatic organic cations in $\left(\mathrm{C}_{9} \mathrm{H}_{14} \mathrm{~N}\right)_{2} \mathrm{HgCl}_{4}$.

TABLe 3: Selected bond distances and angles of the cationic entities $\left(\mathrm{C}_{9} \mathrm{H}_{14} \mathrm{~N}\right)^{+}$.

\begin{tabular}{|c|c|c|c|}
\hline \multicolumn{2}{|c|}{ Distances $(\AA)$} & \multicolumn{2}{|c|}{ Angles $\left({ }^{\circ}\right)$} \\
\hline $\mathrm{C} 1-\mathrm{C} 2$ & $1.392(9)$ & $\mathrm{C} 2-\mathrm{C} 1-\mathrm{C} 6$ & $123.8(6)$ \\
\hline $\mathrm{C} 1-\mathrm{C} 6$ & $1.393(10)$ & $\mathrm{C} 1-\mathrm{C} 2-\mathrm{C} 3$ & $115.9(7)$ \\
\hline $\mathrm{C} 2-\mathrm{C} 3$ & $1.399(10)$ & $\mathrm{C} 4-\mathrm{C} 3-\mathrm{C} 2$ & $121.8(7)$ \\
\hline $\mathrm{C} 3-\mathrm{C} 4$ & $1.370(12)$ & $\mathrm{C} 5-\mathrm{C} 3-\mathrm{C} 2$ & $120.3(7)$ \\
\hline $\mathrm{C} 4-\mathrm{C} 5$ & $1.360(12)$ & $\mathrm{C} 4-\mathrm{C} 5-\mathrm{C} 6$ & $121.6(8)$ \\
\hline $\mathrm{C} 5-\mathrm{C} 6$ & $1.390(9)$ & $\mathrm{C} 5-\mathrm{C} 6-\mathrm{C} 1$ & $116.7(7)$ \\
\hline $\mathrm{C} 10-\mathrm{C} 11$ & $1.385(9)$ & $\mathrm{C} 11-\mathrm{C} 10-\mathrm{C} 15$ & $124.1(5)$ \\
\hline $\mathrm{C} 10-\mathrm{C} 15$ & $1.393(9)$ & $\mathrm{C} 12-\mathrm{C} 11-\mathrm{C} 10$ & $116.7(7)$ \\
\hline $\mathrm{C} 11-\mathrm{C} 12$ & $1.380(9)$ & $\mathrm{C} 13-\mathrm{C} 12-\mathrm{C} 11$ & $121.2(7)$ \\
\hline $\mathrm{C} 12-\mathrm{C} 13$ & $1.365(11)$ & $\mathrm{C} 12-\mathrm{C} 11-\mathrm{C} 10$ & $116.7(7)$ \\
\hline $\mathrm{C} 13-\mathrm{C} 14$ & $1.372(11)$ & $\mathrm{C} 12-\mathrm{C} 13-\mathrm{C} 14$ & $120.7(6)$ \\
\hline $\mathrm{C} 14-\mathrm{C} 15$ & $1.386(9)$ & $\mathrm{C} 13-\mathrm{C} 14-\mathrm{C} 15$ & $121.1(7)$ \\
\hline $\mathrm{C} 19-\mathrm{C} 20$ & $1.379(9)$ & $\mathrm{C} 20-\mathrm{C} 19-\mathrm{C} 24$ & $116.2(7)$ \\
\hline $\mathrm{C} 19-\mathrm{C} 24$ & $1.397(10)$ & $\mathrm{C} 19-\mathrm{C} 20-\mathrm{C} 21$ & $121.0(6)$ \\
\hline $\mathrm{C} 20-\mathrm{C} 21$ & $1.381(10)$ & $\mathrm{C} 20-\mathrm{C} 21-\mathrm{C} 22$ & $118.2(7)$ \\
\hline $\mathrm{C} 21-\mathrm{C} 22$ & $1.381(11)$ & $\mathrm{C} 23-\mathrm{C} 24-\mathrm{C} 19$ & $120.9(7)$ \\
\hline $\mathrm{C} 22-\mathrm{C} 23$ & $1.358(11)$ & $\mathrm{C} 29-\mathrm{C} 28-\mathrm{C} 33$ & $120.8(7)$ \\
\hline $\mathrm{C} 23-\mathrm{C} 24$ & $1.384(11)$ & $\mathrm{C} 28-\mathrm{C} 29-\mathrm{C} 30$ & $119.7(7)$ \\
\hline $\mathrm{C} 28-\mathrm{C} 29$ & $1.383(11)$ & $\mathrm{C} 31-\mathrm{C} 30-\mathrm{C} 29$ & $121.1(9)$ \\
\hline $\mathrm{C} 28-\mathrm{C} 33$ & $1.389(11)$ & $\mathrm{C} 32-\mathrm{C} 31-\mathrm{C} 30$ & $120.6(9)$ \\
\hline $\mathrm{C} 29-\mathrm{C} 30$ & $1.410(13)$ & $\mathrm{C} 31-\mathrm{C} 32-\mathrm{C} 33$ & $121.3(11)$ \\
\hline $\mathrm{C} 30-\mathrm{C} 31$ & $1.361(17)$ & $\mathrm{C} 28-\mathrm{C} 33-\mathrm{C} 32$ & $117.4(9)$ \\
\hline $\mathrm{C} 31-\mathrm{C} 32$ & $1.358(17)$ & & \\
\hline C $32-C 33$ & $1.390(11)$ & & \\
\hline $\mathrm{N} 1-\mathrm{C} 1$ & $1.470(7)$ & & \\
\hline $\mathrm{N} 2-\mathrm{C} 10$ & $1.477(7)$ & & \\
\hline $\mathrm{N} 3-\mathrm{C} 19$ & $1.462(8)$ & & \\
\hline $\mathrm{N} 4-\mathrm{C} 28$ & $1.475(8)$ & & \\
\hline
\end{tabular}

3.7. Electric Conductivity. To better understand the phenomenon of electrical conduction, we will use the equation of Arrhenius' law [45]:

$$
\sigma . T=A \exp \left(\frac{-\mathrm{Ea}}{K \beta . T}\right),
$$

where $\mathrm{Ea}$ is the activation energy, $T$ is the absolute temperature, $K \beta$ is the Boltzmann constant, and $A$ is a constant depending on the material. Figure 12 shows the curve of plotting $\ln (\sigma, T)$ versus $1000 / \mathrm{T}$. This graph is formed by three regions (I), (II), and (III) and two breaks between 301 and $471 \mathrm{~K}$. Each domain is presented by an 


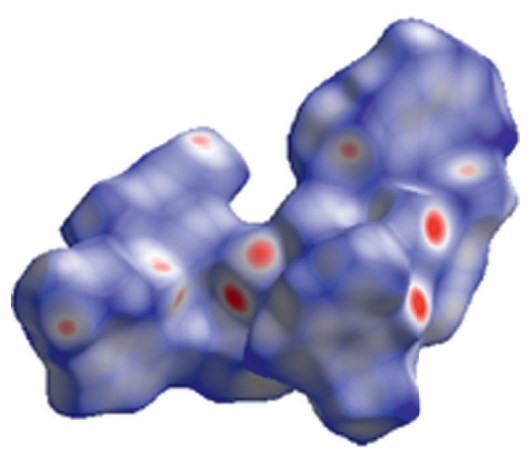

(a)

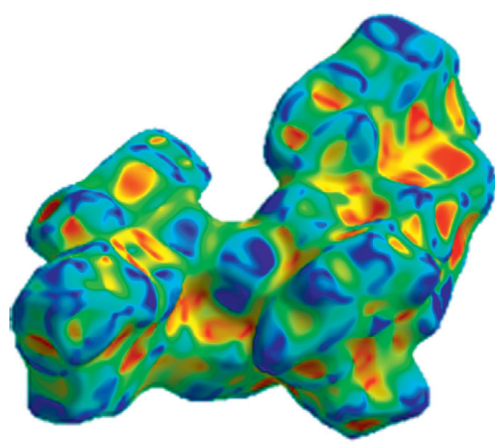

(b)

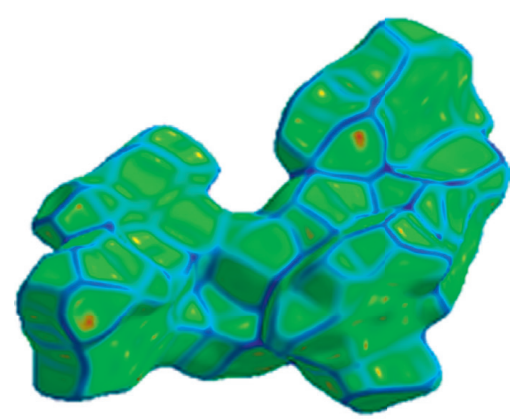

(c)

FIGURE 7: HS cartography with $d_{\text {norm }}$ (a), shape index (b), and curvedness (c) for $\left(\mathrm{C}_{9} \mathrm{H}_{14} \mathrm{~N}\right)_{2} \mathrm{HgCl}_{4}$.

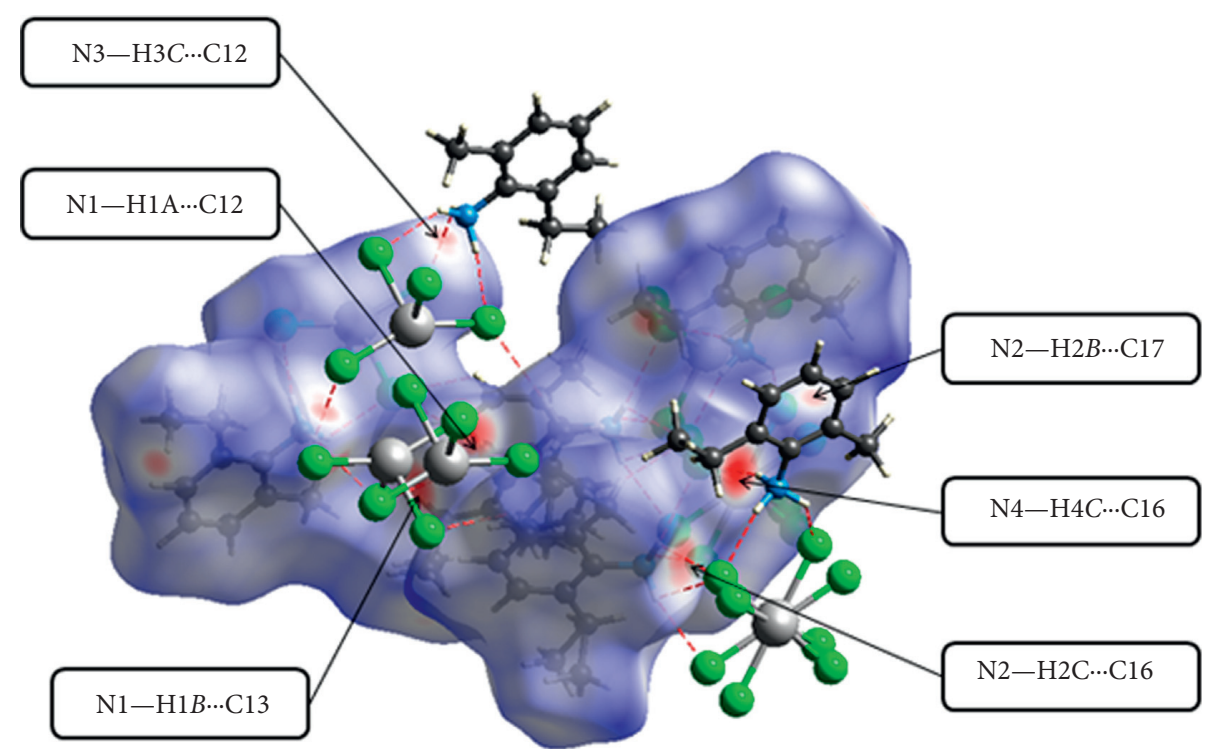

FIGURE 8: Observed hydrogen bonds in the salt by $d_{\text {norm }}$.

affine straight line which is in accordance with Arrhenius' law. The first break is observed at $393 \mathrm{~K}$, with an activation energy of $0.59 \mathrm{eV}$, and (II), with an activation energy of $4.21 \mathrm{eV}$. The second break is observed at $368 \mathrm{~K}$ for which the activation energy of (I) is $0.60 \mathrm{eV}$. A slope change at this temperature was observed in the DTA curve due to two endothermic peaks at 362 and $391 \mathrm{~K}$, respectively. In the studied temperature interval, the conductivity increases with temperature showing that this material behaves like a semiconductor [46]. 


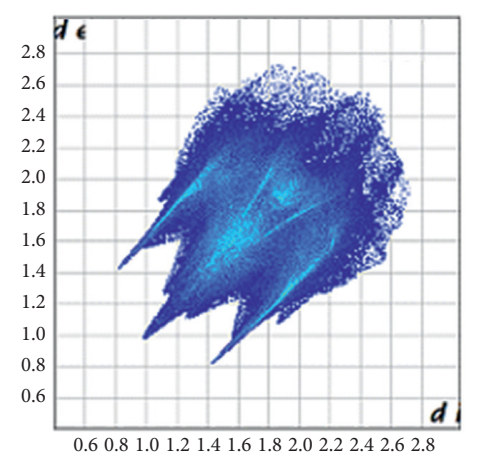

(a)

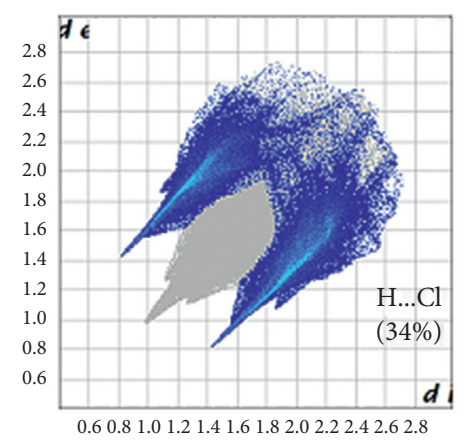

(c)

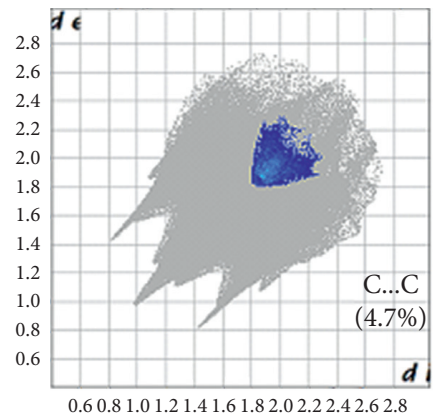

(e)

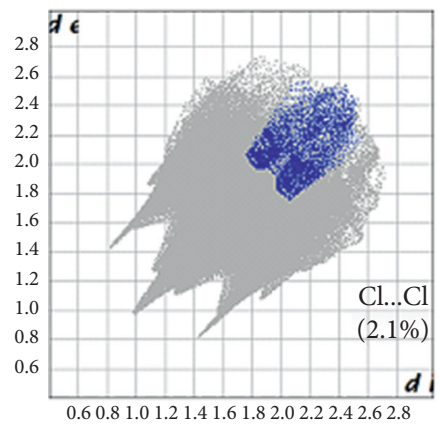

(g)
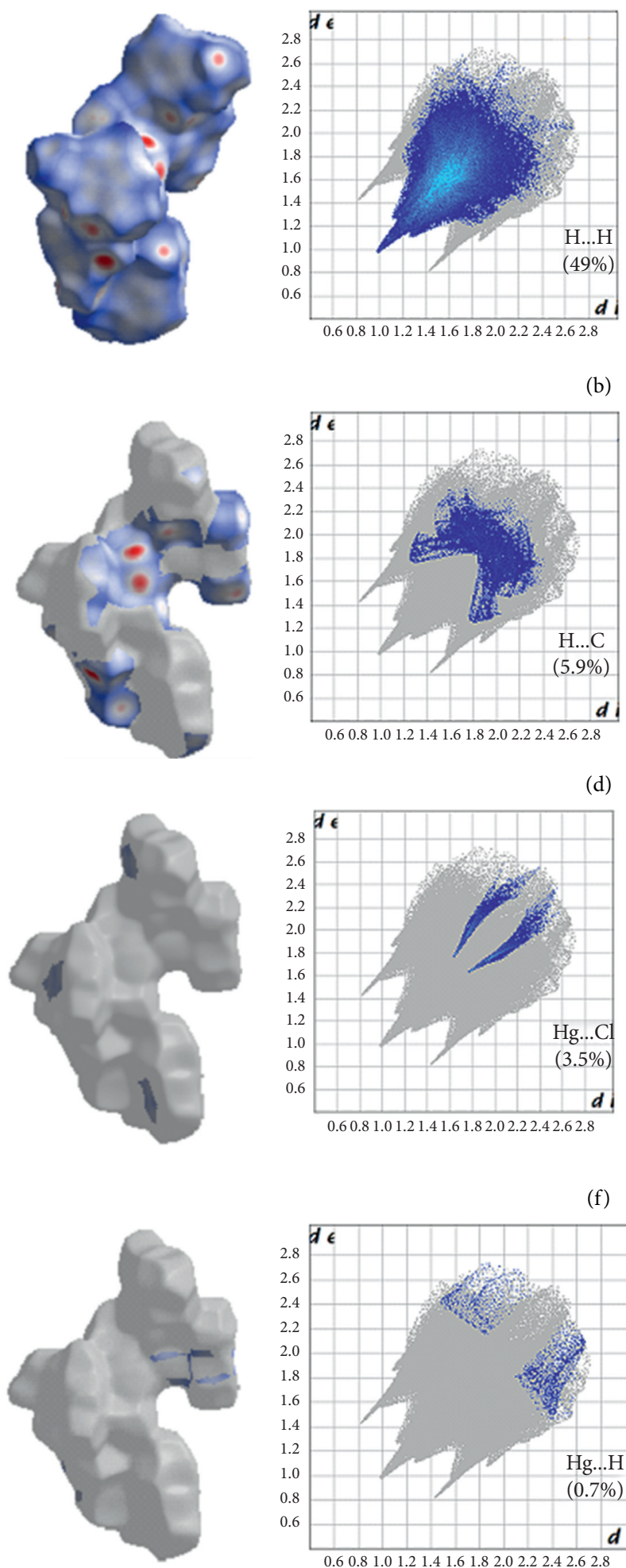

(b)

(d)

(f)
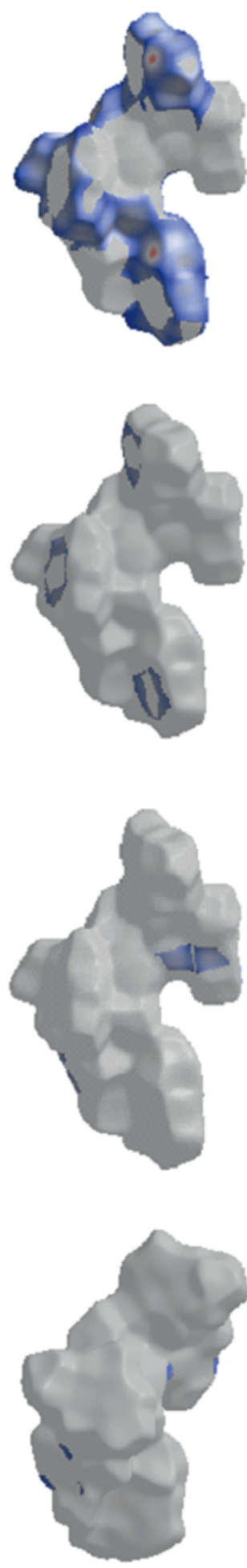

(h)

FIgUre 9: The two-dimensional fingerprint plots for $\left(\mathrm{C}_{9} \mathrm{H}_{14} \mathrm{~N}\right)_{2} \mathrm{HgCl}_{4}$. 


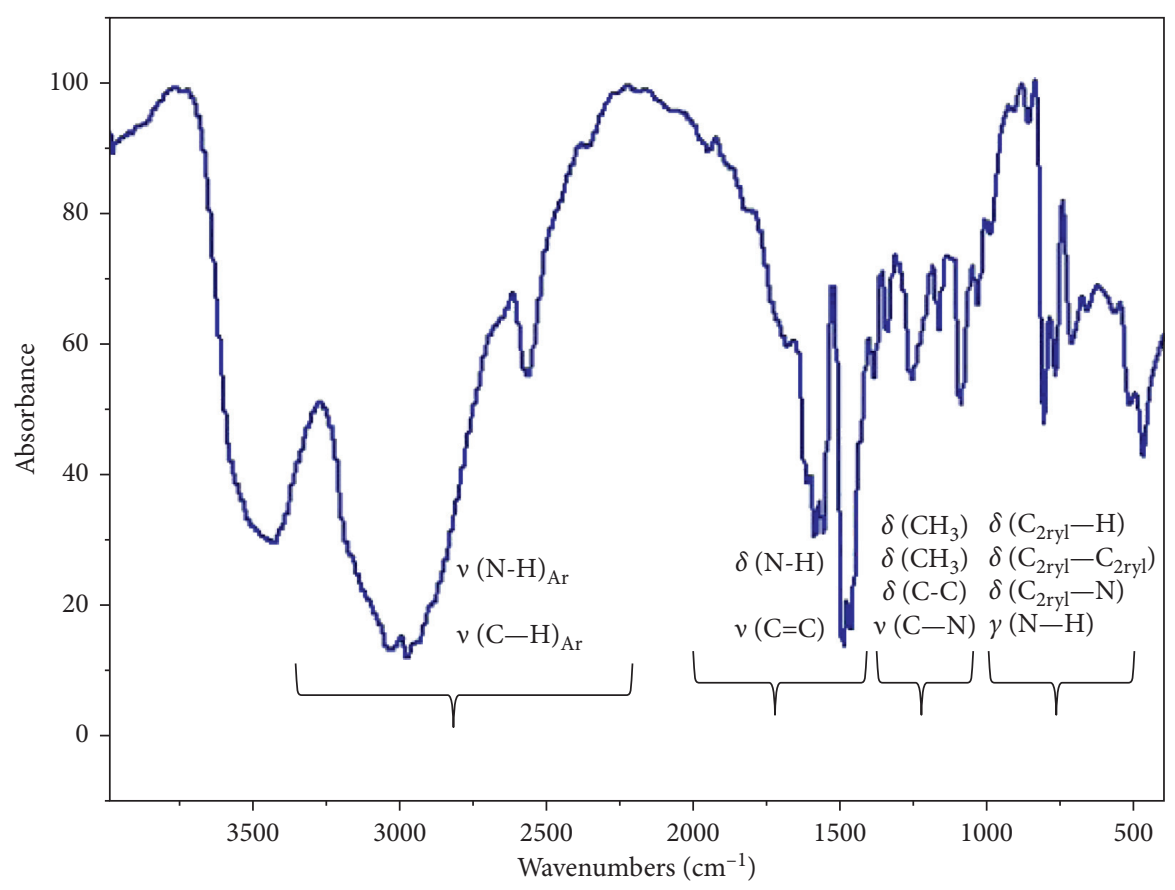

Figure 10: The experimental infrared absorption spectra of $\left(\mathrm{C}_{9} \mathrm{H}_{14} \mathrm{~N}\right)_{2} \mathrm{HgCl}_{4}$.

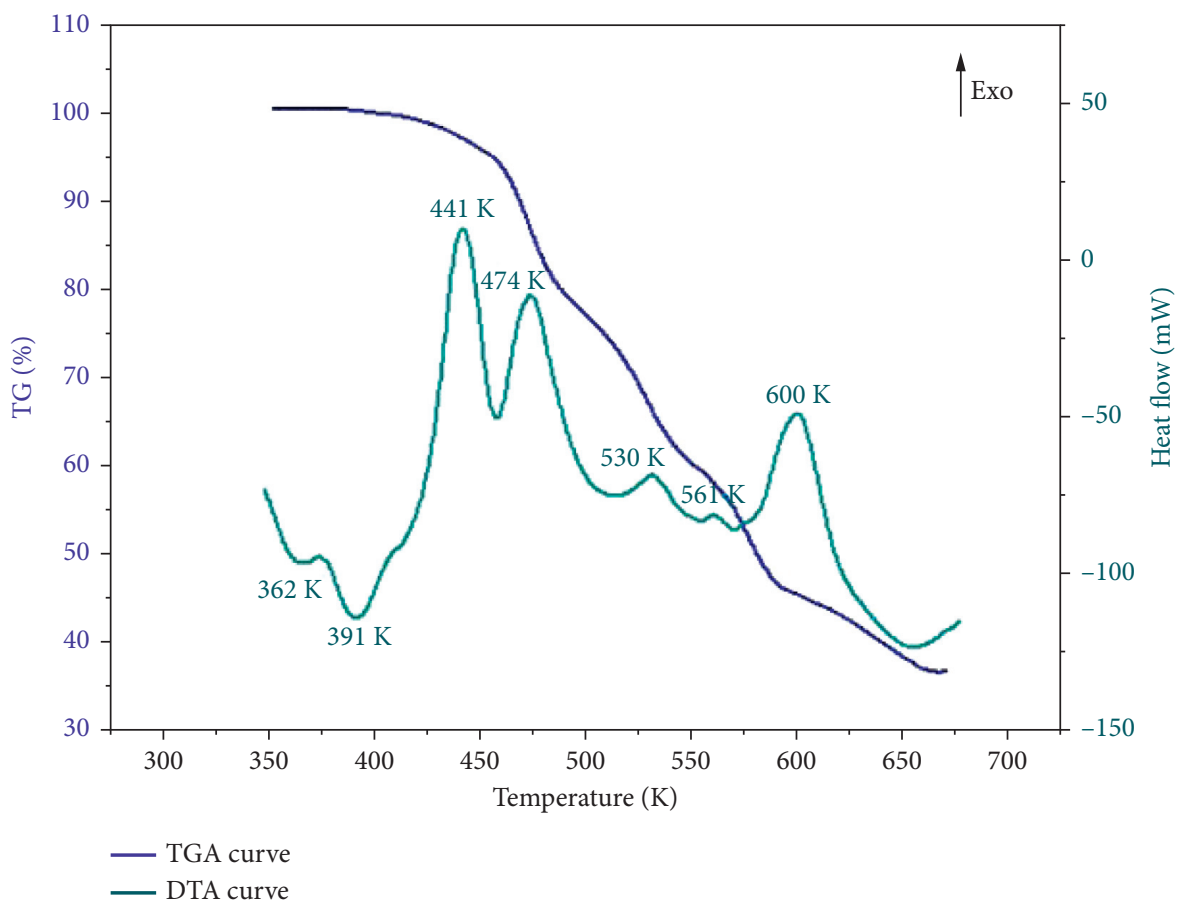

Figure 11: TGA/DTA curves for $\left(\mathrm{C}_{9} \mathrm{H}_{14} \mathrm{~N}\right)_{2} \mathrm{HgCl}_{4}$. 


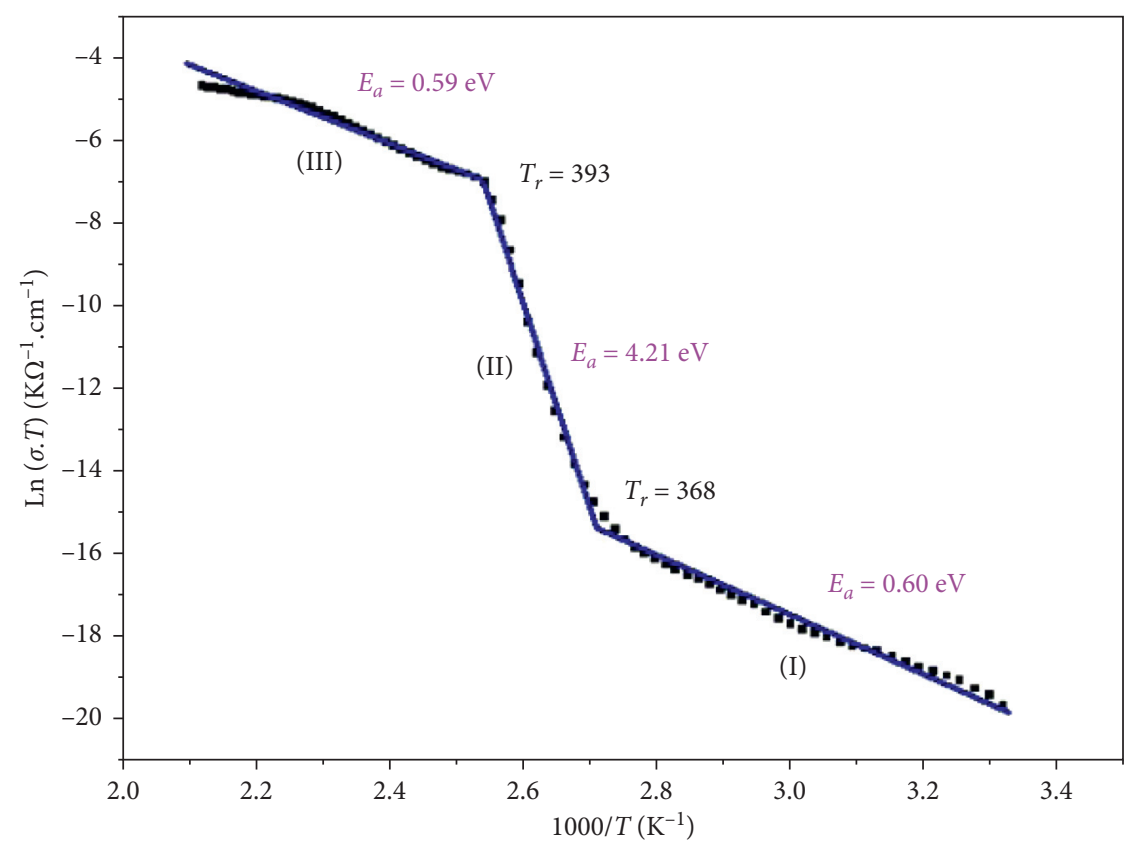

Figure 12: Variation of $\ln (\sigma \mathrm{T})$ versus $1000 / \mathrm{T}$ for $\left(\mathrm{C}_{9} \mathrm{H}_{14} \mathrm{~N}\right)_{2} \mathrm{HgCl}_{4}$.

\section{Conclusion}

This work is devoted to synthesizing a new organic compound of formula $\left(\mathrm{C}_{9} \mathrm{H}_{14} \mathrm{~N}\right)_{2} \mathrm{HgCl}_{4}$. The X-ray diffraction analysis revealed that this compound crystallized in the monoclinic system with $\mathrm{P} 21 / \mathrm{c}$ space group. The crystal structure showed an alteration of anionic and cationic entities. The structure cohesion was manifested by both strong and weak hydrogen bonds as well as $\pi-\pi$ interactions. The HS analysis showed that $\mathrm{H}$...H intermolecular interactions exemplify most of the total surface. The PXRD was proportionally homogenous with the single crystal. The functional groups of the crystal were assigned using FT-IR spectroscopy based on the observed bands. SEM/EDX was also realized to determine the morphology and constituents of the complex, respectively. The thermal analysis clarified that this compound is stable up to $370 \mathrm{~K}$. The conductivity study reveals the presence of two transition phases already detected by thermal analysis using DTA-TGA measurements.

\section{Data Availability}

Crystallographic data for the structural analysis have been deposited at the Cambridge Crystallographic Data Centre (CCDC no. 2074859). These data can be obtained free of charge via http://www.ccdc.cam.ac.uk/conts/retrieving.html or from CCDC, 12 Union Road, Cambridge, CB2 1EZ, UK: fax: (+44) 01223-336-033; e-mail: deposit@ccdc.cam.ac.

\section{Conflicts of Interest}

The authors declare that they have no conflicts of interest.

\section{Acknowledgments}

This work was supported by the Taif University Researchers Supporting Project (number TURSP-2020/272), Taif University, Taif, Saudi Arabia.

\section{Supplementary Materials}

Table S1: selected bond distances and angles of the anionic entities $\left[\mathrm{Hg}(1) \mathrm{Cl}_{4}\right]^{2-}$ and $\left[\mathrm{Hg}(2) \mathrm{Cl}_{4}\right]^{2-}$. Table S2: Hirshfeld contact surfaces and enrichment reports of $\left(\mathrm{C}_{9} \mathrm{H}_{14} \mathrm{~N}\right)_{2} \mathrm{HgCl}_{4}$. (Supplementary Materials)

\section{References}

[1] T. J. Lukianova, V. Kinzhybalo, and A. Pietraszko, "Crystal structure of new organically templated copper sulfate with 2aminopyridinium," Acta Crystallographica Section E Crystallographic Communications, vol. 71, no. 11, pp. m191-m192, 2015.

[2] T. J. Bednarchuk, V. Kinzhybalo, O. Bednarchuk, and A. Pietraszko, "Synthesis, structural characterization, IR- and Raman spectroscopy, magnetic properties of new organically templated metal sulfates with 4-aminopyridinium," Journal of Molecular Structure, vol. 1120, pp. 138-149, 2016.

[3] T. J. Bednarchuk, V. Kinzhybalo, and A. Pietraszko, "Synthesis, structure and characterization of five new organically templated metal sulfates with 2-aminopyridinium," Acta Crystallographica Section C Structural Chemistry, vol. 72, no. 5, pp. 432-441, 2016.

[4] Z. Czapla, S. Dacko, and A. Wa kowska, "Ferroelectric phase transition in hydrogen-bonded 2-aminopyridine phosphate (NC4H4NH2) H3PO4," Journal of Physics: Condensed Matter, vol. 15, no. 22, pp. 3793-3803, 2003. 
[5] I. Bayar, L. Khedhiri, R. Fezai, P. S. Pereira da Silva, M. R. Silva, and C. Ben Nasr, "A hybrid perchlorate with a low band gap: crystal structure, physicochemical characterization and Hirshfeld surfaces study," Journal of Molecular Structure, vol. 1181, pp. 300-304, 2019.

[6] I. Bayar, L. Khedhiri, F. Lefebvre, V. Ferretti, and C. Ben Nasr, "Crystal structure, Hirshfeld surfaces computational study and physicochemical characterization of two new organic salts of 2-chlorobenzylamine, (ClC7H6NH3).NO3 and (ClC7H6NH3).ClO4," Journal of Molecular Structure, vol. 1179, pp. 171-180, 2019.

[7] I. Bayar, R. Kefi, P. Sidonio Pereira da Silva, M. Ramos Silva, and C. Ben Nasr, "3-(Ammoniomethyl)pyridinium bis(perchlorate)," Acta Crystallographica Section E Structure Reports Online, vol. 69, no. 6, p. o843, 2013.

[8] K. Edwards, S. N. Herringer, A. R. Parent et al., "Transition metal halide salts of 8-methylquinolinium: synthesis and structures of (8-methylquinolinium)2 $\mathrm{MX} 4 \cdot \mathrm{nH} 2 \mathrm{O}(\mathrm{M}=\mathrm{Cu}$, Co, $\mathrm{Zn} ; \mathrm{X}=\mathrm{Cl}, \mathrm{Br} ; n=0,1)$," Inorganica Chimica Acta, vol. 368, no. 1, pp. 141-151, 2011.

[9] S. Pal, R. Samanta, and A. K. Pal, "Single crystal EPR studies of $\left(\mathrm{NH}_{4}\right)_{2} \mathrm{CuCl}_{4} \cdot 2 \mathrm{H}_{2} \mathrm{O}$," Physica Status Solidi (B), vol. 179, pp. 37-40, 1993.

[10] I. A. Oxton and O. Knop, "Infrared evidence of a low-temperature transition in (NH4)2CuCl)4.2H2O," Chemical Physics Letters, vol. 49, no. 3, pp. 560-562, 1977.

[11] W. Nolting, "Theory of ferromagnetic semiconductors," Physica Status Solidi B, vol. 96, no. 1, pp. 11-54, 1979.

[12] H. Yamazaki, "Spin-wave relaxation in K2CuF4," Journal of the Physical Society of Japan, vol. 45, pp. 419-1420, 1978.

[13] L. Menabue, G. C. Pellacani, A. Albinati, F. Ganazzoli, F. Cariati, and G. Rassu, "Synthesis and low-frequency vibrational spectra of $\mathrm{N}$-(2-ammoniumethyl)- piperazinium halide-mercurates(II). Crystal structure of $\mathrm{N}$ - $(\Leftarrow$ moniumethyl)- piperazinium monochloride tetrachloromercurate(II)," Inorganica Chimica Acta, vol. 58, pp. 227-231, 1982.

[14] I. M. Vezzosi, A. Benedetti, A. Albinati, F. Ganazzoli, F. Cariati, and L. Pellicciari, "Spectroscopic and structural investigation on tetrahalomercurates(II). Crystal and molecular structures of bis(N-ethylmorpholinium) tetrachloromercurate(II) and (N-ammoniumethylmorpholinium) tetrachloromercurate(II) complexes," Inorganica Chimica Acta, vol. 90, no. 1, pp. 1-7, 1984.

[15] H. R. Khavasi and B. Mir Mohammad Sadegh, "Effect of robust $\pi-\pi$ stacking synthon on the formation of mercury coordination compounds; an unusual pseudo-square planar geometry," Dalton Transactions, vol. 43, no. 14, pp. 5564-5573, 2014.

[16] G. Chillemi, G. Mancini, N. Sanna et al., "Evidence for sevenfold coordination in the first solvation shell of $\mathrm{Hg}$ (II) Aqua Ion," Journal of the American Chemical Society, vol. 129, no. 17 , pp. 5430-5436, 2007.

[17] M. E. Carnes, N. R. Lindquist, L. N. Zakharov, and D. W. Johnson, "Counterion and steric effects in self-assembled HgX2-thioether coordination polymers," Crystal Growth \& Design, vol. 12, no. 3, pp. 1579-1585, 2012.

[18] A. Azhdari Tehrani, A. Morsali, and M. Kubicki, "The role of weak hydrogen and halogen bonding interactions in the assembly of a series of $\mathrm{Hg}$ (ii) coordination polymers," Dalton Transactions, vol. 44, no. 12, pp. 5703-5712, 2015.

[19] B. Ballesteros and L. Santos, "A reinvestigation of the molecular structures, vibrations and rotation of methyl group in o-methylaniline in S0 and S1 states studied by laser induced fluorescence spectroscopy and ab initio calculations," Spectrochimica Acta Part A: Molecular and Biomolecular Spectroscopy, vol. 58, no. 5, pp. 1069-1081, 2002.

[20] L. Santos, E. Martínez, B. Ballesteros, and J. Sanchez, "Molecular structures and vibrations of $\mathrm{m}$-methylaniline in the S0 and S1 states studied by laser induced fluorescence spectroscopy and ab initio calculations," Spectrochimica Acta Part A: Molecular and Biomolecular Spectroscopy, vol. 56, no. 10, pp. 1905-1915, 2000.

[21] K. Halvorson and R. D. Willett, "Structures of ethylenediammonium tetrabromocuprate (II) and propylenediammonium tetrabromocuprate(II)," Acta Crystallographica Section C Crystal Structure Communications, vol. 44, no. 12, pp. 2071-2076, 1988.

[22] G. V. Rubenacker and J. E. Drumheller, "Magnetic susceptibility of [NH3(CH2) NH3] CuCl4Br4(1-) with $n=5$ and 7," Journal of Magnetism and Magnetic Materials, vol. 79, no. 1, pp. 119-121, 1989.

[23] M. Govindarajan, M. Karabacak, S. Periandy, and D. Tanuja, "Spectroscopic (FT-IR, FT-Raman, UV and NMR) investigation and NLO, HOMO-LUMO, NBO analysis of organic 2,4,5-trichloroaniline," Spectrochimica Acta Part A: Molecular and Biomolecular Spectroscopy, vol. 97, pp. 231-245, 2012.

[24] W. B. Trenz, K. Narayanan, C. Y. hsich, and C. C. Tung, "Structures and vibrations of ortho-, meta-, and para-fluoroanilines in the S0 and S1 states by ab initio calculations and resonant two-photon ionization spectroscopy," Journal of the Chemical Society, Faraday Transactions, vol. 93, pp. 29812987, 1997.

[25] M. E. Vaschetto, B. A. Retamal, and A. P. Monkman, "Density functional studies of aniline and substituted anilines," Journal of Molecular Structure: THEOCHEM, vol. 468, no. 3, pp. 209-221, 1999.

[26] S. Y. Lee, S. Park, H. J. Kim, J. H. Jung, and S. S. Lee, "Ligandand anion-directed assembly of exo-coordinated Mercury(II) halide complexes with O2S2-Donor Macrocycles," Inorganic Chemistry, vol. 47, no. 6, pp. 1913-1915, 2008.

[27] S. R. Batten, A. R. Harris, K. S. Murray, and J. P. Smith, "Crystal engineering with mercuric chloride," Crystal Growth \& Design, vol. 2, no. 2, pp. 87-89, 2002.

[28] C. F. Mercury, P. R. Macrae, P. Edgington et al., "Mercury: visualization and analysis of crystal structures," Journal of Applied Crystallography, vol. 39, pp. 453-457, 2006.

[29] A. K. Chandra and C. A. Coulson, "394. Electrophilic reactions of the anilinium cotation," Journal of the Chemical Society (Resumed), vol. 394, pp. 2210-2215, 1965.

[30] M. E. Abdelhamid, T. Murdoch, T. L. Greaves, A. P. O'Mullane, and G. A. Snook, "High-throughput approach for the identification of anilinium-based ionic liquids that are suitable for electropolymerisation," Physical Chemistry Chemical Physics, vol. 17, no. 27, pp. 17967-17972, 2015.

[31] J. L. Lin, K. C. Lin, and W. B. Tzeng, "Mass-analyzed threshold ionization spectroscopy of $\mathrm{o}^{-}, \mathrm{m}-$, , and p-methylaniline cations: vicinal substitution effects on electronic transition, ionization, and molecular vibration," The Journal of Physical Chemistry A, vol. 106, no. 27, pp. 6462-6468, 2002.

[32] L. J. Farrugia, "WinGXsuite for small-molecule single-crystal crystallography," Journal of Applied Crystallography, vol. 32, no. 4, pp. 837-838, 1999.

[33] K. Brandenburg, Diamond Version 2.0, Impact GbR, Bonn, Germany, 1998.

[34] S. K. Wolff, D. J. Grimwood, J. J. McKinnon, D. Jayatilaka, and M. A. Spackman, CrystalExplorer, Version 1.5, University of Western Australia, Perth, Australia, 2007. 
[35] G. A. Jefrey, An Introduction to Hydrogen Bonding, Vol. 12, New York: Oxford University Press, New York, NY, USA, 1997.

[36] R. Elwej, N. Hannachi, I. Chaabane, A. Oueslati, and F. Hlel, "Structural, characterization and AC conductivity of bis-2amino-6-picolinium tetrachloromercurate, (C6H9N2) 2HgCl4," Inorganica Chimica Acta, vol. 406, pp. 10-19, 2013.

[37] M. Loukil, A. Kabadou, P. Salles, and A. Ben Salah, "X-ray diffraction, Raman study and electrical properties of the new mixed compound [Rb0.44(NH4)0.56]2HgCl4.H2O," Chemical Physics, vol. 300, no. 1-3, pp. 247-251, 2004.

[38] S. BelhajSalah, M. S. M. Abdelbaky, S. García-Granda, K. Essalah, C. Ben Nasr, and M. L. Mrad, "Crystal structure, Hirshfeld surfaces computational study and physicochemical characterization of the hybrid material $(\mathrm{C} 7 \mathrm{H} 10 \mathrm{~N}) 2$ [SnCl6]. H2O," Journal of Molecular Structure, vol. 1152, pp. 276-286, 2018.

[39] O. Amri, S. Abid, and M. Rzaigui, "Synthesis and crystal structure of 2.6-xylidinium cyclohexaphosphate tetrahydrate," Analytical Sciences, vol. 24, pp. 277-278, 2008.

[40] M. F. Molano, V. P. Lorett Velasquez, M. F. Erben et al., "Crystal structure, spectroscopic characterization and Hirshfeld surface analysis of aquadichlorido $\{\mathrm{N}-[$ (pyridin-2yl)methylidene]aniline\}copper(II) monohydrate," Acta Crystallographica Section E Crystallographic Communications, vol. 76, no. 2, pp. 148-154, 2020.

[41] W. Smirani and M. Rzaigui, "Crystalline and molecular structure of hydrated 2,6-xylidinium tetrachlorozincate (II)," E-journal of Chemistry, vol. 6, no. 2, pp. 569-576, 2009.

[42] Y. Liu, P. Yang, and J. Meng, "Synthesis, crystal structure and optical properties of a novel organic-inorganic hybrid materials (C9H14N)2PbCl4," Solid State Sciences, vol. 13, no. 5, pp. 1036-1040, 2011.

[43] L. Khedhiri, E. Jeanneau, F. Lefebvre, M. Rzaigui, and C. B. Nasr, "Synthesis and characterization of a new Cyclohexaphosphate, (C9H14N)4(H3O)2(P6O18)," Journal of Chemical Sciences, vol. 128, no. 7, pp. 1037-1045, 2016.

[44] I. Feddaoui, M. S. M. Abdelbaky, S. García-Granda, K. Essalah, C. Ben Nasr, and M. L. Mrad, "Synthesis, crystal structure, vibrational spectroscopy, DFT, optical study and thermal analysis of a new stannate(IV) complex based on 2ethyl-6-methylanilinium (C9H14N)2[SnCl6]," Journal of Molecular Structure, vol. 1186, pp. 31-38, 2019.

[45] K. S. Rao, P. Murali Krishna, D. Madhava Prasad, J.-H. Lee, and J.-S. Kim, "Electrical, electromechanical and structural studies of lead potassium samarium niobate ceramics," Journal of Alloys and Compounds, vol. 464, no. 1-2, pp. 497-507, 2008.

[46] A. C. Dhieb, A. Valkonen, M. Rzaigui, and W. Smirani, "Synthesis, crystal structure, physico-chemical characterization and dielectric properties of a new hybrid material, 1Ethylpiperazine-1,4-diium tetrachlorocadmate," Journal of Molecular Structure, vol. 1102, pp. 50-56, 2015. 